\title{
Neutralizing Cross-Reacting Binding Antidrug Antibody Measurement
}

National Cancer Institute

\section{Source}

National Cancer Institute. Neutralizing Cross-Reacting Binding Antidrug Antibody

Measurement. NCI Thesaurus. Code C147274.

The determination of the neutralizing cross-reactive binding antidrug antibody in a biological sample. 